\title{
段階的砕波係数を導入した 3 次元地形場の 不規則波浪変形計算 COMPUTATION OF RANDOM WAVE TRANSFORMATIONS IN 3-D BATHYMETRY USING GRADATIONAL BREAKER INDEX
}

\author{
合田良実 \\ Yoshimi GODA \\ フエレー，工博 横浜国立大学名誉教授 （株）エコー（T110-0014 東京都台果区北上野 2-6-4）
}

\begin{abstract}
A new system of gradational breaker index is introduced to facilitate the computation of random wave transformations in shallow water. The parabolic equation is used to compute wave shoaling, refraction, and diffraction. Computation is made with multiple levels of wave heights under the Rayleigh distribution. Wave breaking is assumed to occur when the ratio of wave height to local water depth exceeds the breaking index, which takes the largest value for largest wave height level and gradually decreases as the wave height level goes down.

The new system succeeds in reproducing the random wave breaking diagrams by Goda (1975), and shows good agreements with various experimental results on wave transformations over bar and trough topographies, elliptical shoals, and artificial reef systems.
\end{abstract}

Key Words: Random waves, wave breaking, partial breaking indices, wave breaking diagrams, horizontal step, reef, elliptical shoal, artificial reef

\section{1.まえがき}

不規則波の変形計算においては, 砕波の取扱が大 きな課題である. しかし, 砕波時の大規模渦の発生 によるエネルギー消散の過程が非常に複雑であって, その数学的取扱が不可能に近く, 砕波の様相が不規 則波の 1 波毎に異なることもあって, 砕波過程のモ デル化が非常にむずかしい.

浅海域における不規則波浪の砕波変形を扱う際に は，実際の海岸で観察され，あるいは必要とされる 以下の 4 条件を満たすことが求められる.

1) どの水深においても波高の確率密度関数が滑ら かに変化する形状を保つこと.

2) 波高分布が沖合および汀線近傍ではほぼレー リ一分布に近く，砕波帯の中央付近ではこれより も狭い分布形状であること.

3) 初期水深ゼロの汀線においても有限な波高值を 保持すること.

4) バー・トラフ地形など海底勾配が急変する地形 においても合理的な波高值を算出できること.

現状においては，上記の 4 条件をすべて満たす算 定方法は提案されていない。たとえば，著者が1975 年に提案した方式 ${ }^{1)}$ は1)〜3) を満たすけれども，

一様斜面勾配を仮定しているために複雑な海底地形 を扱うことができず，4）の条件を満たさない。

本論文では，放物型方程式による波浪変形計算を
レーリー分布の各波高レベルについて行い，その際に 水深で規定される砕波限界を波高レベル毎に変える方 式を採択する。すなわち段階的砕波係数を導入する. これによって上記の 4 条件をほぼ満足する計算を遂行 できることが明らかになったので，本方式の内容およ びその適用性を各種実験結果で検証した結果について 報告する。

\section{2. 計算モデル}

\section{(1) 放物型方程式}

本論文では，著者が縦型人工リーフの研究2) でこ れまで使用してきた，平口・丸山融による式(1)の放 物型方程式を使用する。この方程式は, 斜め入射 波による屈折効果を的確に解析することができる.

$$
\begin{aligned}
\frac{\partial \phi}{\partial x}= & \left\{i\left(k_{x}+\frac{k_{y}^{2}}{2 k_{x}}\right)-\frac{1}{2 k_{x} c c_{g}} \frac{\partial}{\partial x}\left(k_{x} c c_{g}\right)\right\} \phi \\
& +\frac{i}{2 k_{x} c c_{g}} \frac{\partial}{\partial y}\left(c c_{g} \frac{\partial \phi}{\partial y}\right)-f_{D} \phi
\end{aligned}
$$

ここに, $\phi$ は速度ポテンシャル, $k_{x}, k_{y}$ は $x, y$ 方 向の波数, $c$ は波速, $c_{g}$ は群速度, $i$ は虚数単位であり, 波速は著者による非線形効果 ${ }^{2)}$ 考慮している。ま た， $f_{D}$ は次項に述べる砕波減衰を表す関数である. 


\section{(2) 砕波減衰項の取り扱い}

本論文では縦型人工リーフの解析と同様に, Dally ほが出の考え方に準拠した式(2)の関数を使用する.

$$
f_{D}= \begin{cases}0 & : a<\gamma h \\ \frac{\alpha}{2 h}\left[\left(\frac{a}{\gamma h}\right)^{2}-1\right]^{1 / 2} & : a \geq \gamma h\end{cases}
$$

ここに， $h$ は水深， $a$ は振幅 $(=H / 2$, ここにHは波 高）, $\gamma$ は砕波限界振幅と水深との比， $\alpha$ は定数で あって本論文では縦型人エリープ2) のときに定めた $\alpha=0.125$ の值を用いる. 以下においては，簡単のた めに $\gamma$ を砕波係数と呼ぶ.

\section{（3）不規則波計算用の波高レベルの設定}

規則波の屈折・回折変形に対する放物型方程式を 不規則波に適用するには，まず波高分布の広がりに 対して各波高レベルに関する計算を行い，その結果 を重ね合わせる。ここでは，沖波の波高がレーリー 分布に従うことを前提とし, 式(3)を用いて出現確率 が等しい $M$ 個の波高代表值を求める。これは，レー リ一分布を等面積の $2 M$ 個に分割し，その波高区分 の奇数番目の波高值を採択したものである.

$$
H_{m}=0.706\left(H_{1 / 3}\right)_{0}\left[\ln \frac{2 M}{2 m-1}\right]^{1 / 2}
$$

ここに, 順序数 $m$ は波高の大きい方からの番号で あり，(H $\left.H_{1 / 3}\right)_{0}$ は沖波有義波高である。ただし、これ 以降では簡単のために $H_{0}$ で表記する.

\section{（4）段階的砕波係数の設定}

ここでもし砕波係数 $\gamma$ を全波高レベルに共通に設 定すると, 砕波帯内では波高分布が上限値 $H_{b}=2 \gamma h$ で断ち切られる形となり, 1 .で述べた第 1 の条件を 満たすことができない。 また，このように砕波限界 波高を水深に比例する形に設定したのでは, 初期水 深ゼロの汀線で波高もゼロとなり, 第 3 の条件を満 たすことができない.

このため, 砕波係数を波高レベル毎に式(4)のよう に与えることにした. 式中の $L_{0}$ は (6) 項に述べる各 周波数に対する深海波長, $H_{m}, H_{1}$ は式(3)で求めら れる波高レベル， $i$ はここでは海底勾配であり， $C_{b}$, $\beta_{0}, p$ は経験的定数である. なお, 水深波長比 $h / L_{0}$ が 0.2 を超えるときは砕波減衰が生じないものとみ なし, すべて $h / L_{0}=0.20$ における值を代用する.

$\gamma_{m}=\left(\begin{array}{c}C_{b} \frac{L_{0}}{h}\left\{1-\exp \left[-\frac{1.5 \pi h}{L_{0}}\left(1+15 i^{2.5}\right)\right]\right\} \\ +\beta_{0} \frac{H_{m}}{h}\left(\frac{H_{m}}{L_{0}}\right)^{-0.38} \exp \left(30 i^{2}\right)\end{array}\right) \times\left(\frac{H_{m}}{H_{1}}\right)^{p}$

ここに使われる $C_{b}, \beta_{0}, p$ の定数については，一 様勾配斜面における著者の砕波変形モデルとできる
だけ一致する結果が得られるように，試行錯誤を繰 り返して次のように設定した。

$$
C_{b}=0.080, \quad \beta_{0}=0.016, \quad p=0.333
$$

なお，ここでの砕波係数は式(2)のように振幅に対す る值である. また, この $C_{b}$ 值は波高の分割数 $M$ が 十分に大きい場合であって，Mが小さいときにはや

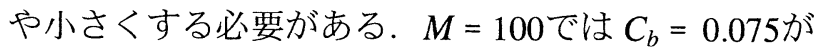
適当である.

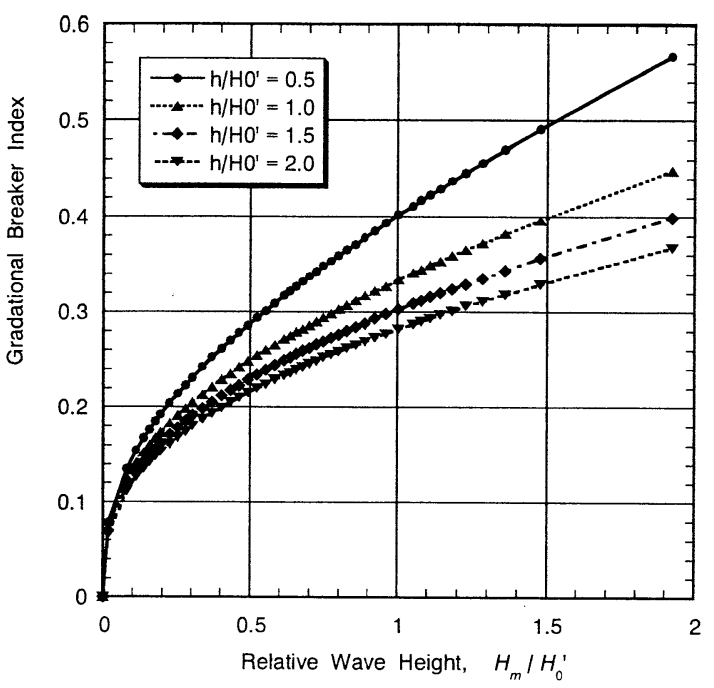

図-1 波高による段階的砕波係数 $\gamma_{m}$ の変化の計算例 （海底勾配 $i=1 / 20, H_{0} / L_{0}=0.04$ ）

式(4)に基づいて段階的砕波係数を計算した例が図 -1である. 成分波数を $M=831$ とし, 相対水深が $h / H_{0}{ }^{\prime}=0.5,1.0,1.5, \& 2.0$ の場合を示している(図中 の記号は序数 $m$ の10番目ごとの值である). 水深が浅 くなるにつれて砕波係数は全体的に大きな值を取る. また, 波高の小さい成分波は砕波係数が小さく設定 される. たとえば, $m=1$ の波高最大の成分波は上記 の相対水深において, 砕波限界波高が水深の $0.73 \sim$ 1.13倍であるのに対し, $H_{m}=0.5 H_{0}$ 'の成分波は砕波 限界が水深の $0.46 \sim 0.62$ 倍に設定される.

なお， $M=831$ としたのは，式(3)において $m=1$ 〜 3個の成分波の波高の平均值が $H_{1 / 250}=1.80 H_{1 / 3}$ の関 係を満たすことを利用し, 著者の砕波変形モデルと の対比を容易にするためである.

\section{（5）複雑地形における勾配の設定法}

リーフや沿岸砂州のような複雑な地形では海底の 勾配が場所ごとに異なる. 波の屈折や回折変形は小 規模な地形変化には反応せず, 波長の数分の一以上 の規模の変化に呼応して波が変形すると考えられる. そこで, 本モデルでは砕波変形計算における海底勾 配として, 計算格子点から沖側へ $\left(L_{p}\right)_{0} / 3$ だけ離れ た格子点の間の水深の差から勾配を求め, 計算地点 の海底勾配とした（負の場合は0とする）。計算を簡 単にするため, 波が斜めに進む場合でも勾配は $x$ 軸 方向に対するものを使用している. 


\section{（6）波向・周波数成分の重ね合わせ法}

海の波は個々波の波高が不規則に変動するだけで なく, 方向スペクトルで表される波向・周波数の広 がりを持っている。本モデルでは（3）項で述べた各 波高レベルの計算を行う度に, 方向スペクトルの広 がりを考慮した線形重称合わせ計算を行う。方向ス ペクトルとしては, JONSWAP型の周波数スペクト ルと光易型方向分布関数の組合せを標準とする.

まず，スペクトルピークの尖鋭度パラメータが 1.0 の場合にエネルギーを等分割する周波数 $f_{n}$ を式 (6)で定める.

$$
f_{n}=1.057 f_{p}\left[\ln \frac{2 N}{2 N-2 n+1}\right]^{-1 / 4}
$$

ここに, $f_{p}$ はスペクトルのピーク周波数であり, 序 数 $n=1$ は最大周波数を表す. 尖鋭度パラメー夕 $\gamma$ が1よりも大きいときには，それによってエネル ギ一密度が増大させられる割合に応じて周波数成分 の本数を増加させる.たとえば， $\gamma=2$ のときは本 数が当初の1.23倍, $\gamma=20$ では4.3倍となる.

成分波の周波数が選定されたならば，あらかじめ その周波数に対する方向分布関数の方向別累加曲線 を作成する。本モデルでは主波向から \pm 0.55 $\pi\left(10 / S_{\max }\right)^{0.35}$ の範囲を 100 等分して累加曲線を求め ている. そして， $[0,1]$ の範囲の一様乱数を使って, その乱数值に対応する方向角を求める.すなわちシ ングル・サンメーション法である．ただしそのまま では, 成分波の波向が主波向のまわりに非対称な分 布形となることが避けられない。このため, 成分波 ごとに主波向に対称な方向の成分波を付加した. し たがって，方向スペクトル成分の個数は $2 N$ である. 全体としての繰り返し計算回数は $M \times 2 N$ となる. 各波高レベルでの方向スペクトル成分の計算結果を 合成する際には，これらの成分波のエネルギーが等 しくなるように設定してあるので, 算術平均方式を 用いる.

\section{3 . 一様勾配斜面における砕波変形}

\section{(1) 砕波に伴う波高確率密度関数の変化}

不規則砕波に関する計算方式の検証としては, 著 者が1975年に提案した, 波高確率密度関数の形状を 砕波に応じて緩やかに整形するモデルがしばしば用 いられる。これを基本モデルと呼んでおく。1.で 述べたように，不規則波の砕波変形計算では沖合か ら汀線に至る各地点の波高分布が滑らかに変化する ことが要求される.

今回の計算方式についてこの点を調べた 1 例が図 -2 である. 成分波数を $M=831$ とし, $H_{0}=4.0 \mathrm{~m}$,

$\left(L_{p}\right)_{0}=100.0 \mathrm{~m}$, 海底勾配 $i=1 / 100$ の条件での計算結 果である。なお，本節では方向分散を導入しない一 方向不規則波を考光, $\gamma=1$ として $N=10$ 成分の計算 を行っている.

波高の確率密度は, 波高の出現頻度を級幅 $\Delta H=$
$0.2 \mathrm{~m}$ で数えた結果から換算した。水深が十分に大き な $h / H_{0}{ }^{\prime}=10.0$ では波高はレーリ一分布に従っている. $h / H_{0}{ }^{\prime}=2.0$ (水深 $\left.8.0 \mathrm{~m}\right)$ では波高 $6.0 \mathrm{~m}$ 以上が砕波のため に姿を消し，その分だけ波高4.0〜 4.6mの出現頻度 が高まる. しかし，それ以下の波高では変化が小さ い. $h / H_{0}{ }^{\prime}=1.5$ (水深6.0m) では波高 $4.6 \mathrm{~m}$ 以上が消えて, その代わりに波高 $2.5 \mathrm{~m}$ 付近に分布のピークが現れる. $h / H_{0}{ }^{\prime}=0.5$ (波高 $2.0 \mathrm{~m}$ )以下ではレーリー分布とほとん ど同じである. 水深が $4.0 \mathrm{~m}, 2.0 \mathrm{~m}$ と減少するにつれ て波高分布が波高の小さい方へ寄っていく.

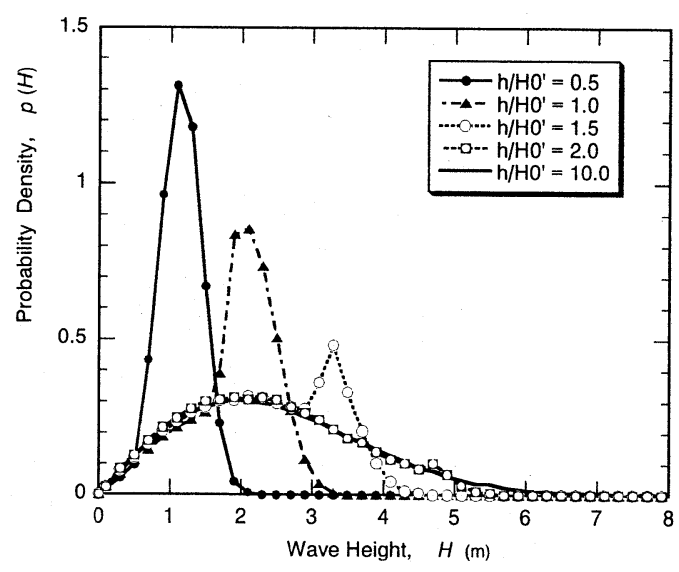

図-2 波高確率密度関数の変化の計算例

このように，砕波帯内で波高分布が二山形になる 難点があるものの, 特定の波高に集中することはな く，実際の波高分布に近い結果となっている.

\section{(2) 一様斜面上の波高変化}

今回の計算方式で一様勾配の海岸における波高の 変化を求めた結果を, 海底勾配 $1 / 20$ のケースについ て図ー3に示す。いずれも最高波高 $H_{\max }$ および $H_{1 / 3}$ の $H_{0}$ 'に対する比として示している. 計算ケースは 波形勾配 $H_{0} / L_{0}=0.02$ と 0.04 である. 基本モデルは 連続曲線, 今回の計算結果はそれぞれの記号で表示 されている。

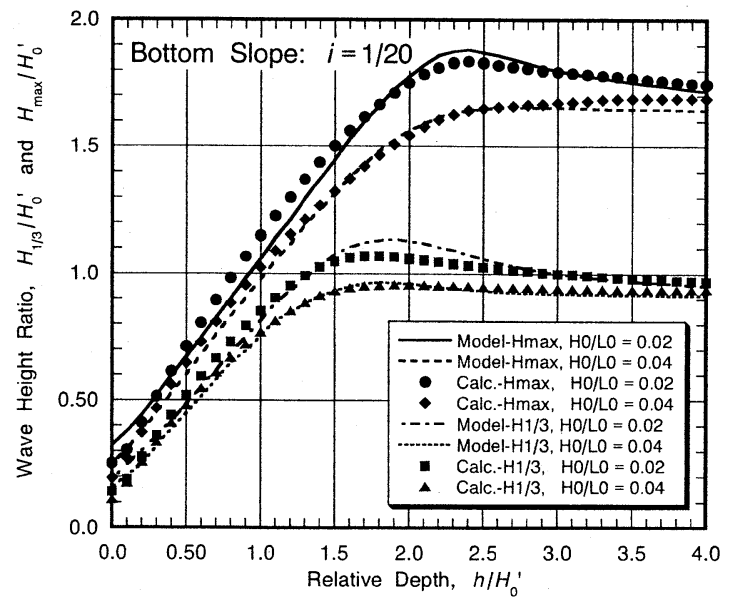

図-3 海底勾配 $1 / 20$ の斜面上の $H_{\max }$ 之 $H_{1 / 3}$ （基本モデルと新方式との比較）

図ー3に見られるように，今回の計算結果は基本 
モデルとほぼ整合している．相対水深 $h / H_{0}{ }^{\prime}=3.0$ 以 上で今回の計算がやや大きいのは，浅水変形に対す るスペクトル導入の影響であり, $h / H_{0}{ }^{\prime}=1.5 \sim 2.5$ の 範囲で逆に小さめとなっているのは, 放物型方程式 が線形計算であり，基本モデルで使われている非線 形浅水効果を取り込んでいないためである.

図示は省略したが，海底勾配 $1 / 10 ， 1 / 30$ および 1/100のケースも今回の計算結果が基本モデルとよ く整合しており，式(4),(5)の段階的砕波係数を用い た計算モデルは，砕波変形に係わる各種の計算に使 用できるものと判断できる.

\section{（3）代表波高間の比率の変化}

新方式の特長は，どの地点においても波高分布を 計算できることである. したがって，砕波帯の中央 付近で波高分布がいったん狭まり，汀線付近で再び 広がる傾向を再現することができる．図ー4 はその 計算結果の一例で，海底勾配 $1 / 30$, 波形勾配 0.04 の 場合である. 波高比としては, $H_{\max } / H_{1 / 3}, H_{1 / 20} / H_{1 / 3}$, および $H_{\text {mean }} / H_{1 / 3}$ の 3 種類を示してある。このうち $H_{1 / 20} / H_{1 / 3}$ は, 斜面被覆材の安定質量の計算に用いら れるパラメータ5)である.

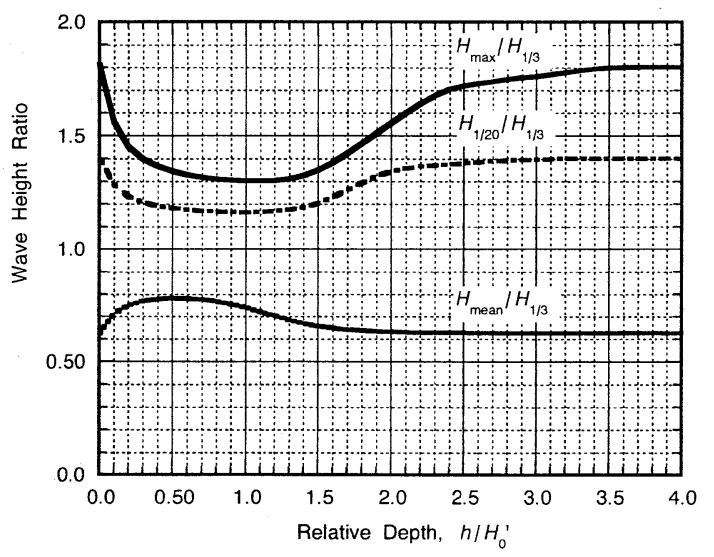

図一4 相対水深による波高比の変化 (海底勾配 $1 / 30 ，$ 波形勾配 0.04 )

今回のモデルによる波高比の変化は, 基本モデル と若干の差があるものの, 砕波帯内の波高変化の様 相をかなり良く再現しているといえる.

\section{4. バー・トラフ地形周辺の波高変化}

現地の海岸では，1列あるいは数列の沿岸砂州が 発達し，それぞれの岸側には水深が深まるトラフが 出現するのが普通である.こうしたバー・トラフ地 形に対する本モデルの適用性について, 実験データ と比較する.

図ー5 は, 權・合田 ${ }^{6)}$ が提示したバー・トラフ地 形での不規則波実験結果と本モデルによる計算結果 を比較したものである.ここに示したのは，バー上 の水深が $9 \mathrm{~cm}$ のときのケースであり, 波浪条件は $H_{0}{ }^{\prime}=10.4 \mathrm{~cm}, T_{1 / 3}=0.98 \mathrm{~s}$ である. 実験值としては
$H_{1 / 3}$ と $H_{\text {mean }}$ のみが提示されているが, 参考として $H_{\max }=H_{1 / 250}$ の計算値も併せて示した.

バーの頂部までの波高変化は本モデルでも的確に 計算できている.バーの頂部を越えたトラフでの波 高は, 本モデルの計算值がやや高めである。これは, 波が砕けて進行する過程での乱流渦によるエネル ギー逸散のプロセスが, Dally型砕波減衰方式では十 分に表現できないためと思われる。

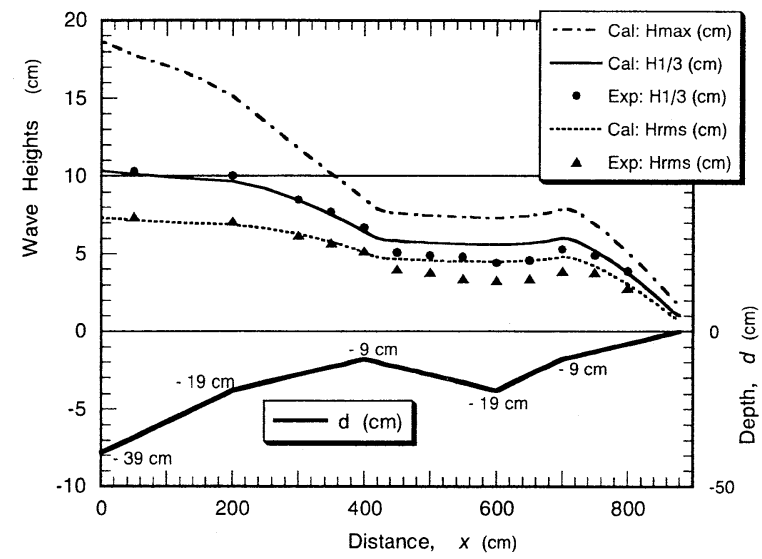

図-5 バー・トラフ地形における実験值と計算值 の比較 : $H_{0}{ }^{\prime}=10.4 \mathrm{~cm}, T_{1 / 3}=0.98 \mathrm{~s}$

さらに大型の実験データとして, Kraus et al. ${ }^{7)}$ が 報告したSUPERTANK と名付けられた海浜変形実験 プロジェクトがある. $H_{0}{ }^{\prime}=60 \sim 80 \mathrm{~cm}$ の不規則波を 一様勾配の砂斜面に作用させ, 海浜変形 ・波・流れ を測定した.このうちの顕著なバーの発達が見られ たケースS0913Aの害験値を計算值と比較したのが 図ー6である.なお，海浜地形は入力を簡略化する ために折れ線形状で近似している.

本モデルは, バー周辺での $H_{1 / 3}, H_{\mathrm{rms}}$ の変化を計算 できるものの, バーの背後で実験值の減衰が大きく, 計算值がこれに追随しきれていない.この傾向は, 權・合田 ${ }^{6)}$ の実験デー夕の場合と同様である. なお, どちらかといえば $H_{1 / 3}$ のほうが実験值と計算値の差 が少ない。

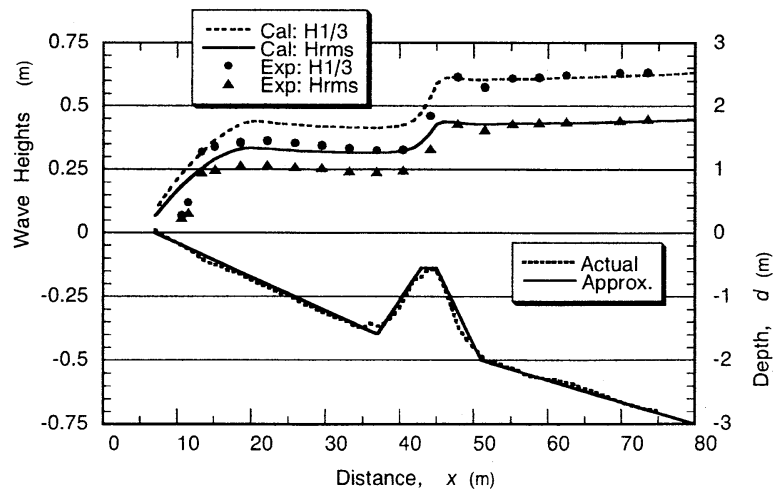

図-6 SUPERTANKの波高変化の実験値と計算値の 比較: ケースS0913A, $H_{0}{ }^{\prime}=0.632 \mathrm{~m}, T_{p}=2.8 \mathrm{~s}$

Larsen $^{8)}$ は不規則波の砕波変形モデルを発表し, このSUPERTANKのデータについてその適用性を検 
証している。しい，バ一背後の強い波高減衰は本 モデルの計算と同様にうまく再現できておらず，計 算值が過大である. Dally型挽波減衰方式を用いてい るためであり，実験值との乘離の具合も同程度であ る.なお, Larsenのモデルでは $H_{\mathrm{rms}}$ 值しか出力され ないのに対し, 本モデルでは $H_{1 / 3}$ をはじめとして, 砕波帯内の各種代表波高を計算できることが特長で あり, 構造物の設訃訃算等への適用範囲が広い.

\section{6. 楕円形浅瀬周辺の波高变化}

本モデルの基本である放物型方程式は，屈折・回 折が併存する波浪変形場に適用することができる. 円形あるいは棈円形浅瀬はその頂部付近に屈折した 波が集中し，そこから回折波が新たに発生すること が知られている。この現象を多方向不規則波を使つ て実験的に調べたのが Vincent・Briggs"

Vincent とBriggs は, 幅 $35 \mathrm{~m}$, 奥行き $29 \mathrm{~m}$ の多方 向造波平面水槽内に, 底面の長径が $3.96 \mathrm{~m}$, 短径が $3.05 \mathrm{~m}$ の棈円形浅瀬を設置した. 周辺の水深は一様 で $0.457 \mathrm{~m}$, 浅瀬の頂部水深は $0.157 \mathrm{~m}$ である. 楕円 の長径は造波板と平行であり, 棈円形浅瀬の中心は 造波板から $6.096 \mathrm{~m}$ の位置にある。

実験波は, TAM型周波数スペクトルと正規分布 型方向関数の組み合わせで与えており, 前者は尖鋭 度パラメータ $\gamma$, 後者は方向分散の標準偏差角 $\sigma_{m}$ で その特性が表される。この論文では光易型方向分布 関数を用いているので，ほぼ同一の $\sigma_{m}$ を与える $S_{\max }$ の值を選んだ. なお, スペクトルピーク周期は すべて $T_{p}=1.3 \mathrm{~s}$ である.

数值計算は, 格子間隔を $\Delta x=\Delta y=0.1524 \mathrm{~m}$ とし, $x$ 方向111格子, $y$ 方向 151 格子を用いた. 周波数 波向成分は一方向不規則波のU3ケースが 24 , 方向 分散角が $\sigma_{m}=10^{\circ}$ と小さいNシリーズが $2 N=130$,

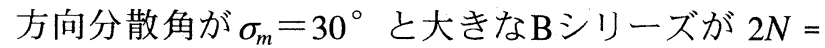
148である. 波高レベルの分割数は, $M=60$ とし, 式 (5)の砕波係数の定数は $C_{b}=0.075$ に低減したものを 用いた。パソコンによる計算時間は，1ケース30分 程度であった。

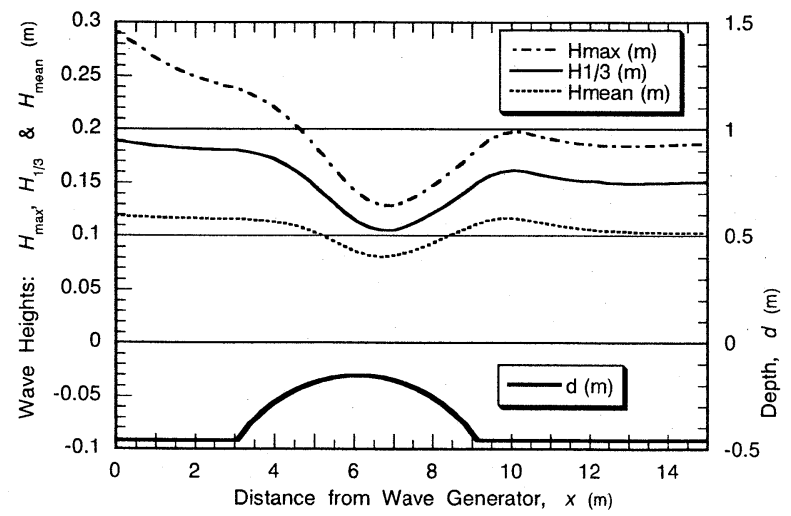

図-7 浅瀬中心軸を通る縦断方向の波高分布 （ケースB5：代表波高の差異による比較）
まず図ー7 は， $H_{1 / 3}=19.0 \mathrm{~cm}$ のケースB5 の縦断方 向の波高の計算結果であり, $H_{\max }, H_{1 / 3}$ および $H_{\text {mean }}$ が浅瀬の頂部で砕波減衰のために減少し, 浅 瀬の背後でやや増大する状況を示している. なお, 浅瀬前方の一様水深部でも減衰が始まっているのは, 水深 $45.7 \mathrm{~cm}$ に対して有義波高が $19 \mathrm{~cm}$ とかなり大 きいためである.

波高測定の実験結果が提示されているのは，浅瀬 中心から $6.1 \mathrm{~m}$ 後方の Transect 4 と名付けられた横 断面に沿ったもので，沖波波高に対する波高比とし てグラフ化されている. その值を図から読みとって 計算値と比較したのが図ー8，9である.

図-8 は一方向不規則波であるU3および方向分 散の小さな N4，N5 のケースにおける計算値と実験 值の比較である. 有義波高はU 3 と 4 が $2.54 \mathrm{~cm}, \mathrm{~N} 5$ が $19.0 \mathrm{~cm}$ である. 波高の小さなU3とN4では, 実験 值之計算値がよく一致し, 放物型方程式で浅瀨周辺 の波高分布を的確に求められることを示している.

有義波高が $19.0 \mathrm{~cm}$ と大きくて砕波影響の著しい N 5 のケースでは, 波高分布の傾向が実験と計算でずれ ている.ただし, 横断面全体の平均值で見ると, 計 算値と実験値はほぼ合致している.

図－9 は, 有義波高 $2.54 \mathrm{~cm}$ のケースB3および波 高 $19.0 \mathrm{~cm}$ のケースB5についての比較である. 前者 の計算值は実験とほぼ一致しているが，後者は波高 分布の傾向にやや食い違いがある. なお, Dr. Briggs よりN3とN4, B5 とN5が入れ替わって論文に記載さ れたとの連絡があり, 真值をプロットしている.

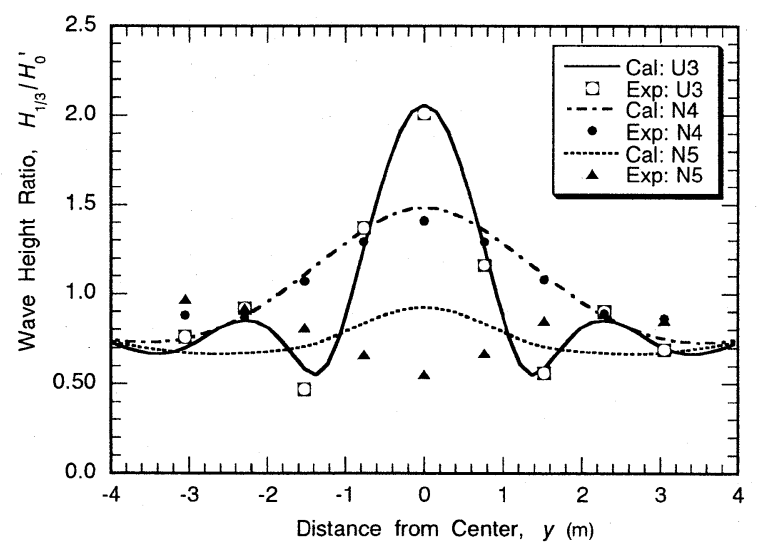

図-8 方向分散が狭い実験ケースと計算との比較 （浅瀬中心から $6.1 \mathrm{~m}$ 後方のTransect 4の断面）

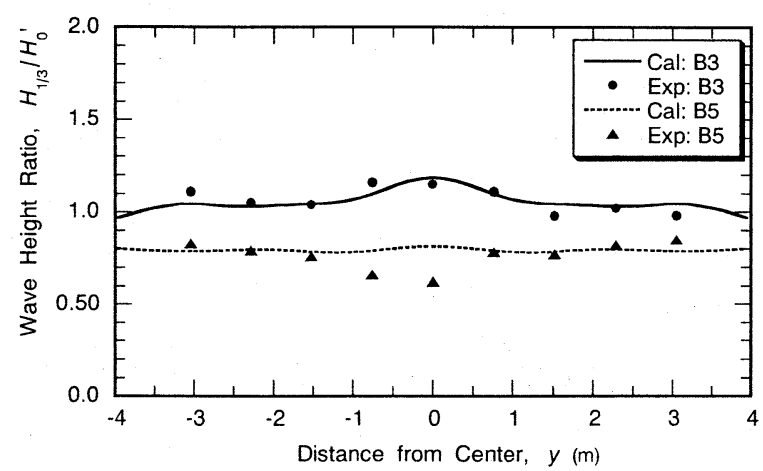

図-9 方向分散が広い実験ケースと計算との比較 （浅瀬中心から $6.1 \mathrm{~m}$ 後方のTransect 4の断面） 


\section{7. 人エリーフ周辺の波高変化}

著者は先に縦型人エリーフの構想を提唱し，水理 模型実験と放物型方程式による計算を行い，通常の 人エリーフとの比較を行った ${ }^{2)}$.この実験デー夕の うち，人エリーフについて本モデルで波高分布を計 算した結果を図一10,11に示す。なお，実験デー夕 は文献 ${ }^{10)}$ に記載の図に基づく.

人エリーフは，沿岸方向の天端長が $100 \mathrm{~cm}$, 岸沖 方向の天端幅が $45 \mathrm{~cm}$ ，天端水深が $3 \mathrm{~cm}$ の寸法であ り，勾配 $1 / 20$ の一様斜面上に 2 基を中心間隔 $1.8 \mathrm{~m}$ で設置した。図ー10は 2 番目の人エリーフのほぼ 中央を横断する岸沖方向の波高分布を示す。波は Bretschneider-光易型スペクトルの不規則波 2 種類を 用い, いずれも入射角 $-15^{\circ}$ で一様水深 $30 \mathrm{~cm}$ の地 点から $1 / 20$ 勾配斜面に斜め入射させている．計算格 子間隔は $\Delta x=\Delta y=5 \mathrm{~cm}$ である. なお，図ー11の 水深図は測定位置ではなく, リーフの設置状況が分 かるように水深 $12.5 \mathrm{~cm}$ の場所のものを示している.

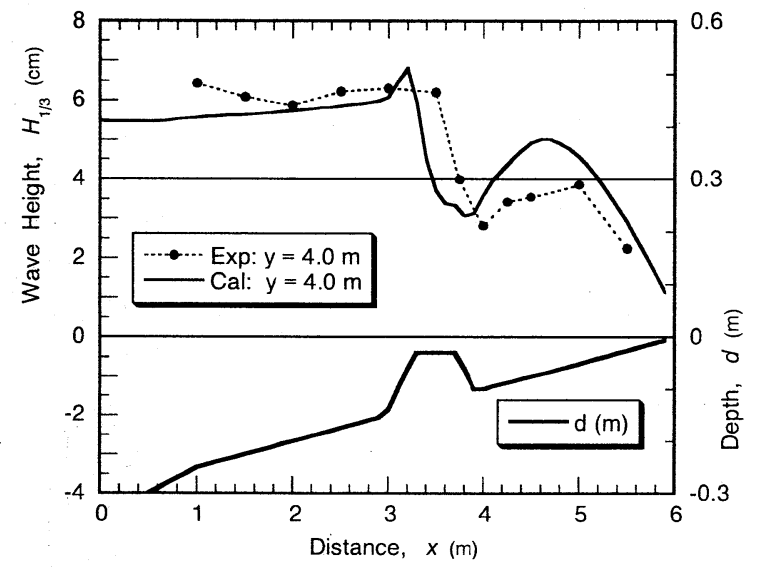

图一10 $\left(H_{1 / 3}\right)_{\mathrm{I}}=5.5 \mathrm{~cm}, T_{1 / 3}=1.6 \mathrm{~s}$ の不規則波に対する 人エリーフ横断面の岸沖方向の波高分布

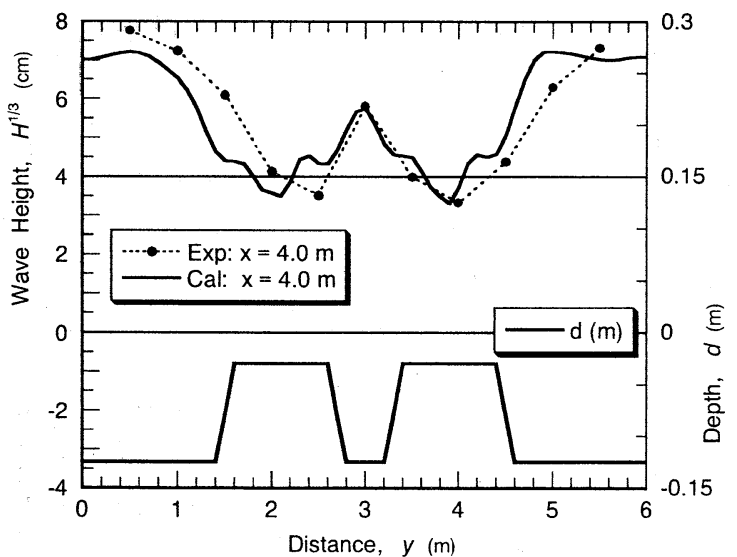

図-11 $\left(H_{1 / 3}\right)_{\mathrm{I}}=7.5 \mathrm{~cm}, T_{1 / 3}=1.2 \mathrm{~s}$ の不規則波に対する人 エリーフ背後の沿岸方向の波高分布（水深 $10.0 \mathrm{~cm}$ )

これらの結果を見ると，実験値と計算值に若干の 差異があるものの，全体としては数値モデルが人工 リーフ周辺の波高分布をかなりよく再現しており, こうした人工構造物への適用性を例証している.

\section{8. むすび}

複雑な形状の海底地形に対して砕波を伴う波浪変 形を求める手法として, 新しい方法を提案した。 そ の要点および結論は以下の通りである.

1。砕波による波浪減衰を求める際に，水深に対す る砕波限界波高比を波高のレベルごとに段階的 に変える方式を案出した。これを段階的砕波係 数と呼ぶ。

2. 計算は，あらかじめ設定した多数の波高レベル ごとに行い，方向スペクトルから求められる成 分波の全てについての計算結果をエネルギ一的 に合成する.

3. 段階的砕波係数に含まれる経験的定数を調整し た結果，一様斜面における合田(1975)の砕波波 高算定図表とよく一致する結果が得られた。

4. 砕波帯内で波高の確率密度分布が徐々に変化す る傾向も再現することができた。

5. バー・トラフ地形, Vincent と Briggs (1989) が 提示した楕円形浅瀬，および人エリーフのよう な複雑な地形についても，実験值とかなり合致 する計算結果が得られ，こうした複雑地形に対 する適用性が確認できた。

\section{参考文献}

1)合田良実：浅海域における波浪の砕波変形，港湾技術 研究報告, 第14巻, 第3号, pp.59-106, 1975 .

2)合田良実 : 屈折効果を利用した縦型人エリーフシステ ムの特性について，土木学会論文集，No.663/II-53, pp.55-67, 2000.

3)平口博丸, 丸山康樹: 斜め入射波に対する放物型方程 式の適用性の拡張, 第33回海岸工学講演会論文集, pp.114-118, 1986.

4) Dally, W.R., Dean, R.G., and Darlymple, R.A.: Wave height variation across beaches of arbitrary profile, J. Geophys. Res., Vol.90, No.C6, pp.11,917-11,927, 1985.

5)運輸省港湾局監修: 港湾の施設の技術法の基準・同解 説, 日本港湾協会, pp.153-154, 1999.

6)權七ュタシ・合田良実: バー型地形における不規則波の砕 波変形について, 海岸工学論文集, 第42巻, pp.101-105, 1995.

7) Kraus, N.C., Smith, J. M., and Sollitt, C.K.: SUPERTANK laboratory data collection project, Proc. 23rd ICCE, Venice, ASCE, pp.2191-2204, 1972.

8) Larsen, M.: Model for decay of random waves in surf zone, $J$. Waterways, Port, Coastal and Ocean Engrg., ASCE, Vol.121, No.1, pp.1-12, 1995.

9) Vincent, C.L. and Briggs, M.J.: Refraction-diffraction of irregular waves over a mound, J. Waterways, Port, Coastal and Ocean Engrg., ASCE, Vol. 115, No. 2, pp.269-284, 1989 10)合田良実, 高木泰士 : 人工リーフと縦型傾斜式離岸堤 の水理特性の比較について, 海洋開発論文集, Vol. 13, pp.31-36, 1997. 